\title{
Accounting
}

\section{Human capital, capital structure choice and firm profitability in developing countries: An empirical study in Vietnam}

\author{
Van Chien Nguyen ${ }^{\text {* }}$
}

\begin{tabular}{|c|c|}
\hline CHRON I C L E & A B S T RACT \\
\hline $\begin{array}{l}\text { Article history: } \\
\text { Received October } 142019 \\
\text { Received in revised format } \\
\text { November } 212019 \\
\text { Accepted November } 212019 \\
\text { Available online } \\
\text { November } 212019 \\
\text { Keywords: } \\
\text { Construction sector } \\
\text { Firm profitability } \\
\text { Human capital } \\
\text { Debt } \\
\text { Capital structure choice }\end{array}$ & $\begin{array}{l}\text { The paper aims to examine the impact of human capital, capital structure choice and firm profitability of } 48,673 \\
\text { Vietnamese construction firms in 2016. Measuring firm profitability by return on assets (ROA) or return on equity } \\
\text { (ROE), the results demonstrated that using more debt in capital structure would positively increase the performance } \\
\text { of the firm but this positive effect was increasingly declining. Moreover, evidence showed that human capital had } \\
\text { a positive impact on the result of business activities. A larger size of a firm could positively boost firm performance. } \\
\text { Regarding firm location, a firm locating in the metropolitan of Ho Chi Minh City had a higher level of performance } \\
\text { than a firm locating in the metropolitan of Hanoi capital. Finally, operating status of the firm as well as the } \\
\text { establishment of industrial park had insignificant impacts on firm profitability. }\end{array}$ \\
\hline
\end{tabular}

\section{Introduction}

In the background of the economic global integration and economic growth, Vietnam has experienced such a high economic growth rate, foreign investment attraction, export performance and firm activities expansion (Dollar, 2002; World Bank, 2011). In the construction industry, the 2003 land law reform and the 2013 recent land law, Vietnam has expanded the doors for enterprises doing business in the construction and real estate industry. Foreign investors have been allowed to participate in the wider real estate market, in the first-time foreign investors not only lease long - term land, but also develop apartment blocks and industrial parks, direct engagement in real estate development. Supported by a tremendous economic growth since economic reform in Vietnam in 1986 (called as "Doimoi") and numerous of trade agreements (VCCI, 2019), Vietnam was able to maintain such a high economic growth rate of 7.06\% in the 1990-2008 period. In the parallel with economic development, the construction sector has also contributed an important part to GDP. Fig. 1 shows the contribution of construction industry and highlights that the proportion of construction industry contribution in GDP has slightly decreased, about $5.11 \%-6.39 \%$ of gross domestic product (GDP) during 2005-2018 period and 5.73\% on average. In the most recent three years of 2016-2018, the contribution is stable at $5.62 \% ; 5.74 \%$ and $5.66 \%$ GDP, respectively.

\footnotetext{
* Corresponding author.

E-mail address: chiennv@tdmu.edu.vn or chienmpp3@gmail.com (V.C. Nguyen)
} 


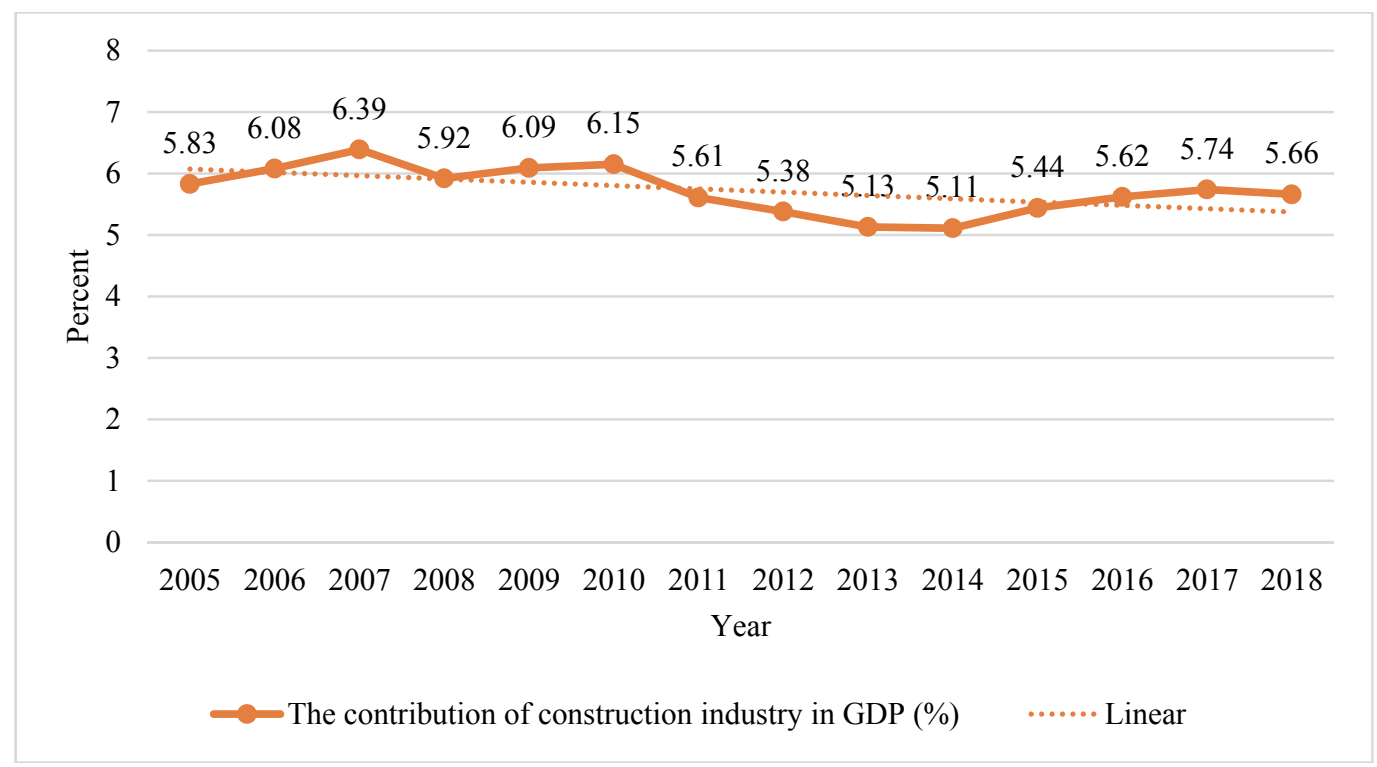

Fig. 1. The contribution of construction industry in GDP (\%)

Source: General Statistics Office (2019).

Fig. 2 shows the trend of economic growth and construction growth since 2005. It is evident that there is an inverse construction industry growth with an uptrend growth in the 2006-2011 period and a downtrend growth in the recent period. In addition, construction industry growth is often cyclical and strongly affected by macroeconomics. During 2005-2018 period, construction industry growth tends to fluctuate with GDP growth in the same direction. In the years of 2006-2011, Vietnam encountered a number of problems such as high public debt, high NPLs (non- performance loans) and slowdown in economic growth. Vietnam returned to the fold of the double-digit inflation is reflected in the high price of goods and services. In 2011, Vietnam's government promulgated the Resolution No.11/NQ-CP on major solutions to focus on curbing inflation, stabilizing macroeconomics and ensuring social security, it negatively impacted on the real estate and construction sector. According to State Bank Vietnam (2012), the real estate market faced many difficulties and was in freefall. As summarized by Resolution No.11/NQ-CP, selling price in all kinds of construction market sectors sharply dropped due to an oversupply of housing in the metropolitans of Hanoi and Ho Chi Minh City. In contrast, economic growth has recovered in order that construction growth has steadily improved since 2011. The phenomenon of housing oversupply has no longer appeared because the construction market has positively grown based on the diversification of some housing segments and the construction industry market. Fig. 2 also shows that construction industry growth would have been $9.7 \%$ in $2015-2018$ period.

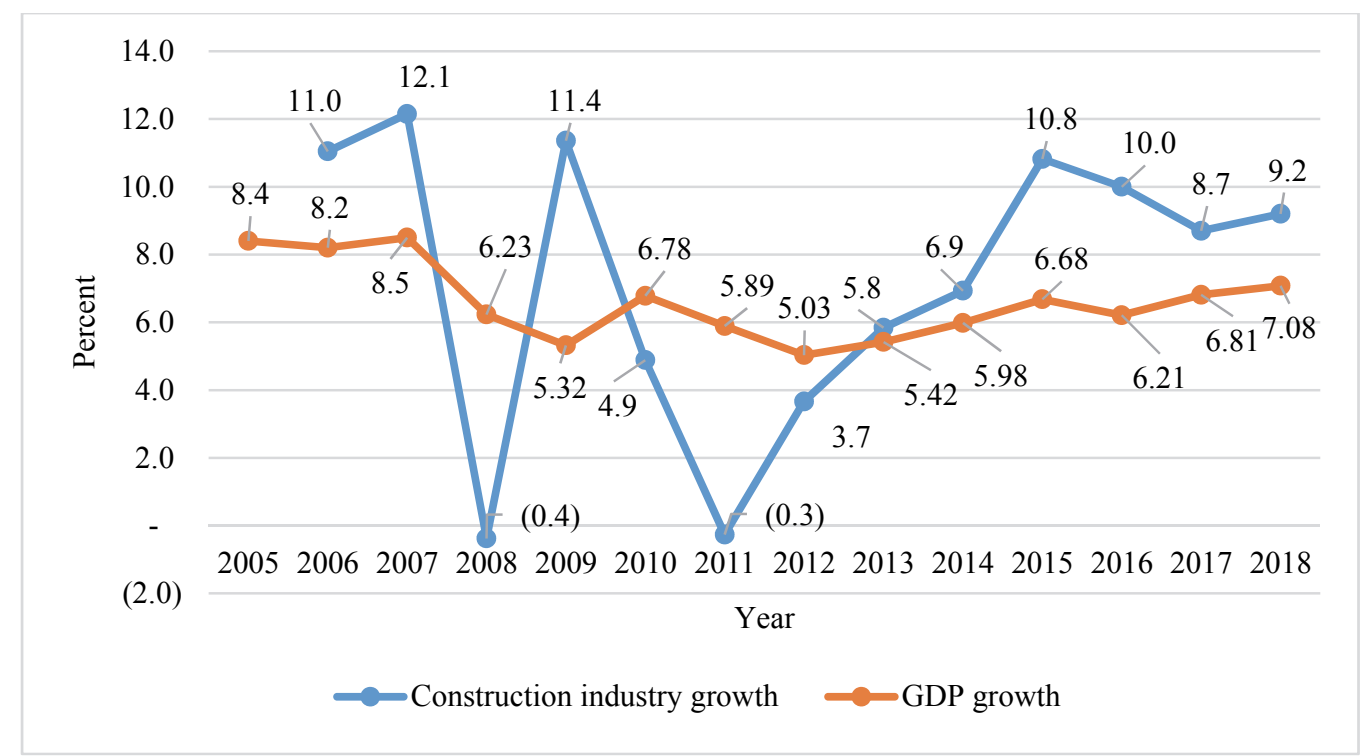

Fig. 2. Growth Rate of Construction Sector and GDP (\%)

Source: General Statistics Office (2019). 
Labor productivity is known as a key indicator to estimate growth quality and drive of change in lifestyle and living conditions. In fact, the growth of the construction industry has also improved its productivity. As shown by Vietnamese National Productivity Institute (2018), the construction industry's productivity in 2008 is around VND 38 million per worker, by 2017 its productivity has already doubled about VND 70 million per worker and in 2018 over VND 75 million per worker. Compared to other industries, the productivity of the construction industry is relatively high and more competitive. Most less developed countries need more capital to boost a high economic growth in order to catch up highly developed countries, in particular, establishment more firms to solve unemployment, enhance productivity and economic growth (OECD, 2002). Fig. 3 pointed out that the number of newly established companies has been continuously increasing, especially over 100.000 new firms per year since 2014. In 2018, Vietnam has 131.3 thousand new businesses. The number of businesses in the construction industry is always in the top 3 with $11 \%$ the labor force attraction, behind retail and wholesale, automobiles and motorcycles repair, processing and manufacturing industries. The proportion of construction firms in total national firms is gradually decreasing from $13.5 \%$ in 2005 to $12.7 \%$ in 2017. As highlighted by Nguyen and Nguyen (2007), the economic growth is also a tool to attract more FDI inflows, more FDI investment projects pouring into the construction sector in Vietnam because construction industry sector needs more unskilled workers, most foreign capital concentrates at low technology and simple manufacturing sector for final goods on import substitution.

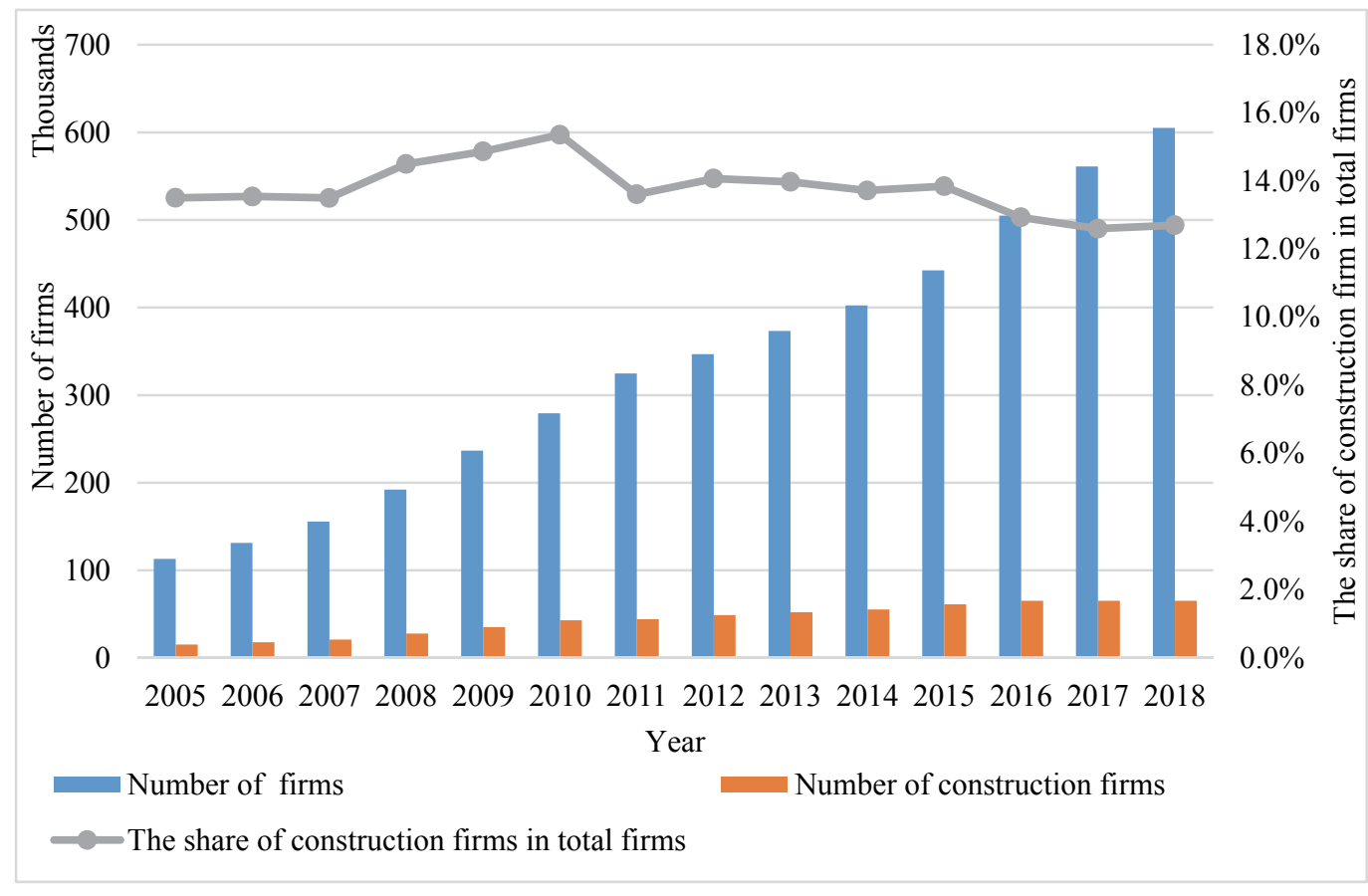

Fig. 3. The Share of Construction Firms in Vietnam during 2005-2018 Period

\section{Literature review}

Source: General Statistics Office (2019).

As presented in some recent papers, the attraction of capital has played a significant role in upgrading technologies and firm performance (Jensen \& Meckling, 1976; Jensen, 1986). Nowadays, a variety of firms are facing competitive pressures to survive and awareness of about how to manage capital structure through financing their business activities and maximize the firm's value. A number of firm-level studies have investigated the capital structure (Adachi-Sato \& Vithessonthi, 2019; Ibhagui \& Olokoyo, 2018; Samagaio \& Rodrigues, 2016; Ruíz et al., 2017; Khan \& Quaddus, 2017). It has been discussed in two theories such as trade-off theory and pecking order theory. First, trade-off theory indicates that a firm can be financed partly with debt and partly with equity in its capital structure whereby that firm has to balance the benefits and the costs in that firm. Trade-off theory eventually supports the benefits of leverage in the capital structure. As suggested in Modigliani and Miller (1963), debt is beneficial in consistent with increasing of firm value because of an increase of tax shield. Using more debt in capital structure, a firm can achieve more value by getting tax shield, the benefits of shareholders will exactly increase. Tax shield is dependent on corporate income tax and the value of debt. Further discussed about optimal capital structure, Modigliani and Miller (1963) also said that the influence of debt in the capital structure can be lasted because of the existence of trade-off cost against the tax shied. In addition to the costs of financial distress as bankruptcy costs of debt and non-bankruptcy costs of debt, the benefit of further increases in debt in the firm will decline if debt increases. In the study of Jensen (1986) mentioned that capital structure may hugely have effect on the performance of a firm. In particular, using debt will force the managers to think how to use the capital more efficiency in order to pay interest, dividends for shareholders and retained earnings for the demand of production 
expansion in future. Another possibility, based on the pecking order theory, the cost of financing will increase with symmetric information. As the study of Myers and Majluf (1984), firms should firstly find out and prioritize internal financing before debt as well as firm equity. If firms have to choose the external financing, firms should choose debt securities from the lowest level to the highest level of risk. Myers and Majluf (1984) also investigated that choosing equity in the capital structure is less preferred due to symmetric information between managers and investors. Specifically, managers want to place their firms a higher value meanwhile investor normally undervalue firm value. However, during the period of macroeconomic fluctuations, high inflation, if a firm is financed by more debt, interest expense is a burden, which can lead that firm to loss profit and low performance. However, Jensen (1986) also pointed out that using of debt is also beneficial due to external pressure from creditors will stimulate the firm to be effective in business. Using debt in the capital structure and outside equity, the agency cost theory is mentioned by Jensen and Meckling (1976). In the study, it indicated that agency cost is defined by the sum of the monitoring expenditures of principal, the bonding expenditures of the agent and the residual loss due to agency relationship as a contract between the principal and the agent as a representative for the principal. More generally, the nature of agency costs is generated by a combination of debt and outside equity. This is a principal-agent problem it is the existence of shareholders and the Chief Executive Officer. In agreement with a rising level of debt in the capital structure, more debt in the capital structure might highly affect managers' behaviors. As Jensen and Meckling (1976) also pointed out that a higher proportion of debt is also connected with the better efficiency of firm.

As presented by Iavorskyi (2013), using a dataset of 16,500 Ukrainian firms over 2001 - 2010, with firm performance measured by return on assets (ROA) or EBIT margin, the study found that leverage which is presented for debt in the capital structure, negatively impact to firm performance, moreover, inverted U-shaped curve in this relationship is also found. If replacing firm performance by TFP, this invert U shaped curve is not found. Iavorskyi (2013) tried to explain that negative effects of leverage on firm efficiency take part in high-growth firms in contrast to positive effects take part in low-growth firms. During the period of time 2001 - 2010, Ukrainian economy maintained a somehow high economic growth whereby it supported more growth to Ukrainian firms. Moreover, the finding of the relationship between leverage and firm performance was unchanged when replacing leverage by long-term leverage. Separating industry sub-samples, manufacturing or transport/energy had a negative affect firm performance but construction, services as well as most of other industries leverage had no effect on efficiency of firm. Another study on a panel dataset of 237 Malaysian companies on the Bursa Malaysia Stock Exchange (BMSE) during the years of 1995 - 2011, Salim and Yadav (2012) found that a higher level of debt rate in capital structure negatively impacts on construction firm efficiency, like the finding of Iavorskyi (2013). However, if separating debt into long-term debt and shortterm debt, the relationship of capital structure choice on firm performance was dualistic. More specifically, firm performance measured by either return on assets (ROA) or return on equity (ROE), there was no effect from either long-term debt (LTD) or short-term debt (STD) on the performance of construction firm. Salim and Yadav (2012) investigated in the stock exchange, when firm performance measured by Earning per Share (EPS), either LTD or STD also negatively affects firm performance. It is to see that an increase in long- term debt or short- term debt in the capital structure choice will decrease the efficiency of the firm. However, this evidence is also found if firm's earnings per share is available.

Another empirical study is estimated by McConnell and Servaes (1995) who conjecture a negative impact from leverage to firm's profitability, however, the negative effects of debt can strongly dominate the positive effects for high-growth firms and the positive effects can also dominate the negative effects for low-growth firms. As explained by McConnell and Servaes (1995) that a firm using debt will have to think the possibility of repayment in the near future, but the project will only obtain positive net cash flow after a few years of its implementation in order that the project would not be profitable in the early stages of business implementation. By a study of Adachi-Sato and Vithessonthi (2019) estimating over some developed and developing countries, it is evident that the maturity of firm debt is negatively generated with the performance of a firm in the future. Vătavu (2015) in a similar study estimated the research over 196 Romanian manufacturing companies listed on the Bucharest Stock Exchange (BVB) during the period 2003 - 2010, the debt ratio was negative significantly associated with the performance of the firm and positive for equity ratio. Results reveal that the performance of the manufacturing firm was higher if the firm chose more equity in the capital structure due to the manufacturing firm did not perform effectively in a capital structure was heavily leveraged. Besides, Hausmans test also concluded that fixed effect method was more suitable. An unresolved problem in the study was concluded that the study did not find any evidence regarding the effect of long-term debt and short-term debt on the firm performance due to missing data. Regarding human capital, a few studies have reported the effects of human capital on the performance of the firm (Samagaio \& Rodrigues, 2016; Lehtimaki \& Lehtimaki, 2016; Ruíz et al., 2017; Khan \&d Quaddus, 2017). Further, Eesley and Roberts (2012) indicated that a company with poor human resources will be very difficult to manage. Thus, businesses are trying to attract more qualified personnel in order to serve the development of the firm. Human capital is defined as diplomas, certificates, knowledge and skills that workers will use in production and business (Ployhart \& Moliterno, 2011). Evaluating human capital, Wignaraja $(2008,2011)$ proposed that this capital is measured by total trained personnel used in the company and also measured by the level of managers. In many cases, a company with high human capital means that company can pay a higher income for its staffs, as in Gashi's research (2014). In addition, a firm's human capital can be divided to demographic factor and psychographic factor, a previous study of Khan and Quaddus (2017) reported that an increase in 
demographic factor and psychographic factor can generate a better firm performance. Investigators have found that human capital can generate the higher effectiveness of the firm (Samagaio \& Rodrigues, 2016; Ruíz et al., 2017; Khan \& Quaddus, 2017). In the Portuguese audit firms, a higher level of human capital could improve a higher of performance (Samagaio \& Rodrigues, 2016). Measuring knowledge capital by a combination of individual capital and organization capital, in the top 500 biggest firms in Finland, Lehtimaki and Lehtimaki (2016) stated that individual capital did not immediately increase the performance of the firm in the short term but immediately generated in the long term. In contrast, organization capital shortly generated the performance of a firm but not in the long run. The evidence is confirmed that investing in individual capital has a greater impact than this in organization capital in the long run. A firm needs to invest more individual capital for long-run growth. Examining on 112 firms in the Spanish Stock Exchange, Ruíz et al. (2017) stated that, creating human capital through developing learning concept can generate firm performance.

The possibility, noted by Nguyen and Nguyen (2015), using panel data procedure for a sample size of 147 Vietnam's companies listed on the Ho Chi Minh City Stock Exchange (HOSE) during the period from 2006 to 2014, reported a negative effect from leverage on firm performance. In addition to debt maturity, there was no difference on the effect of either the long- term debt ratio or the short-term debt ratio on firm performance, a negative effect was still found. It means that a higher level of debt in capital structure will decrease the efficiency of the firm. Regarding firm size, Nguyen and Nguyen (2015) also found a larger firm had a lower cost of bankruptcy and robustness of a higher growth rate which was associated with a higher performance. In contrast, the study also had a warning that if a firm may too much invest in fixed assets, the company would be less effective because the firm needs to pay expense to improve its management process. Regarding firm size, numerous previous studies note that the size of firm probably impacts on firm performance. It is evident that the larger firm has more advantages due to economies of scale when cost per unit of output decreases with increasing scale so that the firms are more efficient in operation. In the analysis of Emin (2016), a firm with a higher level of size will strongly improve firm's performance in the case of Turkey. Similarly, Iavorskyi (2013) also showed that a larger company by size tends to generate a larger proportion of their performance. However, this evidence is not clear, a negative impact or a positive impact is also found dependently on define of firm performance. Similarly, Ibhagui and Olokoyo (2018) indicated that the impact of leverage on firm performance was positive and mostly dependent on the firm size, however, the negative effect is significantly found if a firm were small-sized and this negative effect could diminish when a firm grows.

To the best of our knowledge, no study has focused on human capital in developing countries, especially in the low-middle income countries. In this study, the effects of capital structure and human capital on the performance of a firm were examined.

\section{Methodology}

\subsection{Model}

This research is mainly based on the model of Adachi-Sato and Vithessonthi (2019); Ibhagui and Olokoyo (2018); Ruíz et al. (2017); Khan and Quaddus (2017); Samagaio and Rodrigues (2016) and Salim and Yadav (2012) and a cross-sectional data. The regression function is written as follows:

$$
\begin{aligned}
& \text { ROA }_{i, t}=\alpha_{0}+\beta_{1} \text { LEV }_{i, t}+\beta_{2} \text { LEVSQ }_{i, t}+\beta_{3} \text { SIZE }_{i, t}+\beta_{4} \text { HUMAN }_{i, t}+\beta_{5} \text { OPERATING }_{i, t}+\beta_{6} \text { HANOI }_{i, t}+\beta_{7} \text { HOCHIMINH }_{i, t} \\
& \text { ROE }_{i, t}=\alpha_{0}+\beta_{1} \text { LEV }_{i, \mathrm{t}}+\beta_{2} \text { LEVSQ }_{i, t}+\beta_{3} \text { SIZE }_{i, \mathrm{t}}+\beta_{4} \text { HUMAN }_{i, \mathrm{t}}+\beta_{5} \text { OPERATING }_{\mathrm{i}, \mathrm{t}}+\beta_{6} \text { HANOI }_{\mathrm{i}, \mathrm{t}}+\beta_{7} \text { HOCHIMINH }_{\mathrm{i}, \mathrm{t}}+\varepsilon
\end{aligned}
$$

Either $\mathrm{ROA}_{\mathrm{i}, \mathrm{t}}$ or $\mathrm{ROE}_{\mathrm{i}, \mathrm{t}}$ is a measure for financial performance at the firm $i$ at the time $t$. We have:

$$
\begin{aligned}
\text { ROA } & =\frac{\text { Earnings after Tax }}{\text { Average Total Assets }}=\frac{\text { Net Profit }}{\text { Average Total Assets }} \\
\text { ROE } & =\frac{\text { Earnings after Tax }}{\text { Average Shareholders'Equity }}=\frac{\text { Net Profit }}{\text { TAverage Shareholders'Equity }}
\end{aligned}
$$

Vietnam has two economic hubs, including Hanoi and its surrounding area in the North, Hochiminh and its surrounding area in the South. According to General Statistics Office (2018), the region of HANOI and HOCHIMINH contributed two-thirds GDP, national budget and revenue of construction sector in Vietnam. To clarify the performance of the firm in two hubs, the study is to evaluate this effect.

Table 1 presents the explanatory variables and independent variables as well as expectation about the sign of coefficient in the regression model: 


\section{Table 1}

Variable Definitions

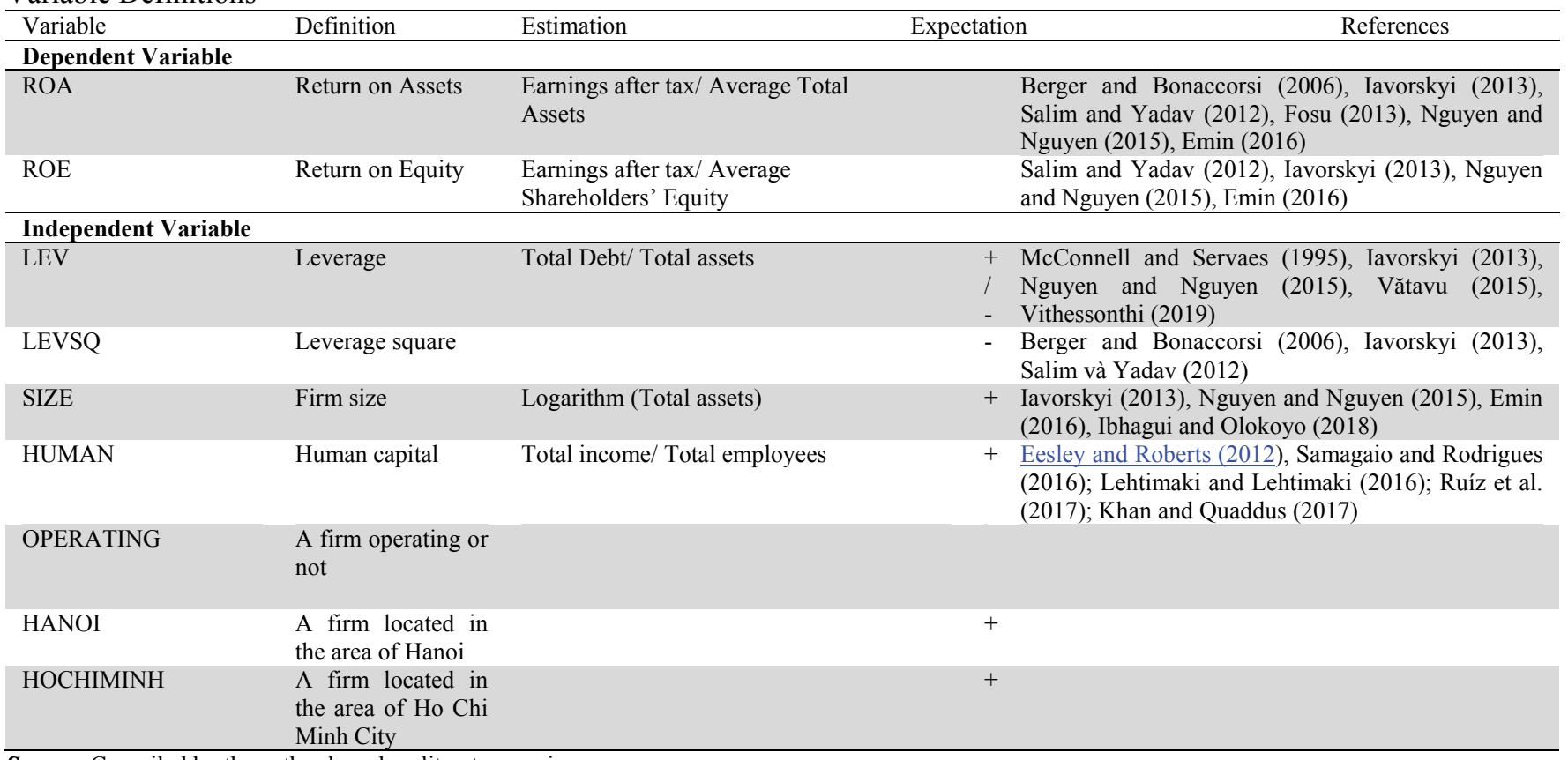

Source: Compiled by the author based on literature review.

In order to analyze the impact of capital structure on firm performance, the paper applies pooled Ordinary Least Squares (OLS) estimation. The cross-sectional data in 2016 is used for the regression with robust error standard in order to solve heteroscedasticity issues to select the best model.

\subsection{Sample Size}

This research has studied over 48.673 construction firms in 2016. The data is retrieved from Vietnamese Firm Database that is yearly published. It consists of: the head office of a firm, the field of a firm, managers (age, qualification, nationality, etc.), firm type, labor information, financial reports (as long-term assets, short-term assets, debt, equity). Currently, the latest dataset was only published in 2016 (2017 and 2018 are unpublished yet). In addition, Vietnamese Firm Database was exclusively surveyed firm's total debt instead of separately surveyed short- debt and long-term debt for 2016 whereby it may affect the selection of the independent variables in the analysis.

\section{Results and discussion}

\subsection{Descriptive Statistics}

Table 2 represents the summary statistics of the sample used in the study, including number of observations, mean, std. deviation, min and max. The average ROA of the sample is -0.0014 (or $-0.14 \%$ ) or ROE is -0.0044 (or $-0.44 \%$ ), this further confirms that the business result in 2016 in the construction industry were not really good. The range of ROA is quite large with the lowest ROA -1.91 (-191\%) and the highest ROA 1.52 (152\%). Similarly, for the range of ROE, the lowest ROE -4.85 ( $-485 \%)$ and the highest ROE 1.97 (197\%). Possible reasons of such low operational performance are originally from the depression of the real estate and bank system during the time 2008 - 2012 (source) or avoiding the tax burden. In terms of leverage, Table 2 shows that the mean of leverage is $38.46 \%$, a large amount of firm is financed by not only equity but also debt. It is evident that Vietnam's construction firms use only $38.46 \%$ debt to finance their assets and $61.54 \%$ equity to finance their assets. Table 3 shows that a firm in the region of Ho Chi Minh City is financed by less debt and more shareholders' equity in the capital structure. With regards to human capital, the mean of human capital is quite low at $2.38 \%$, showing that construction firms use more unskilled workers, on the other hand, the number of observations of this variable is 28.213 and less than other variables due to Vietnamese companies are not willing to show the operational performance. The firm size has an average value of 8.14 , but the range of the firm size is somewhat large. In respect to dummies in the analysis, most of construction firms are in operation $(97.71 \%)$. The Industrial Park has an average value of $0.86 \%$ with a standard deviation $0.92 \%$, indicating that most construction firms are not situated in the industrial park. Table 2 and Table 3 reveal that a majority of construction firms had located in the megalopolis of Hanoi and Ho Chi Minh City with constituting $25.85 \%$ and $40.85 \%$ of the sample, respectively. 
Table 2

Summary Statistics

\begin{tabular}{llllll}
\hline Variable & Observations & Mean & Std. Deviation & Min & Max \\
\hline ROA & 48.673 & -0.0014 & 0.0416 & -1.9161 & 1.5255 \\
ROE & 48.673 & -0.0044 & 0.1225 & -4.8586 & 1.9749 \\
LEV & 48.673 & 0.3856 & 0.3045 & 0 & 1 \\
LEVSQ & 48.673 & 0.2414 & 0.2698 & 0 & 1 \\
SIZE & 48.673 & 8.1471 & 1.9340 & -2.3026 & 16.7299 \\
HUMAN & 28.213 & 0.0238 & 0.0425 & $2.94 \mathrm{e}-07$ & 1.7142 \\
OPERATING & 48.673 & 0.9771 & 0.1498 & 0 & 1 \\
HANOI & 48.673 & 0.2585 & 0.4378 & 0 & 1 \\
HOCHIMINH & 48.673 & 0.4084 & 0.4915 & 0 & 1 \\
INDUSTRIALPARK & 48.673 & 0.0086 & 0.0925 & 0 & 1 \\
\hline
\end{tabular}

Table 3

Number of Companies by Region

\begin{tabular}{lll}
\hline & Number of Companies & Percentage \\
\hline HANOI & 12580 & $25.85 \%$ \\
HOCHIMINH & 19880 & $40.84 \%$ \\
OTHERS & 16213 & $33.31 \%$ \\
\hline
\end{tabular}

Table 4

Capital Structure by Region

\begin{tabular}{lllll}
\hline & Number of Companies & Mean & Std.Dev & Min \\
\hline HANOI & 12580 & $45.55 \%$ & $30.31 \%$ & 0 \\
HOCHIMINH & 19880 & $30.22 \%$ & $30.30 \%$ & 0 \\
OTHERS & 16213 & $43.34 \%$ & $28.27 \%$ & $99 \%$ \\
\hline
\end{tabular}

Notes: This ratio is counted by leverage (total debt over total assets)

Source: Calculated by the author.

\subsection{Empirical Findings}

Based on regression model, the explanatory variable as ROA or ROE and the independent variables like LEV, LEVSQ, SIZE, HUMAN, OPERATING, HANOI, HOCHIMINH and INDUSTRIALPARK. Table 3 presents the regression results of test of the relationship between capital structure and ROA, ROE.

Table 5

Firm Performance Measured by ROA or ROE

\begin{tabular}{|c|c|c|c|c|}
\hline & ROA & ROA & ROE & ROE \\
\hline $\mathrm{C}$ & $\begin{array}{l}-0.018 \\
(-2.40)^{*}\end{array}$ & $\begin{array}{l}-0.019 \\
(-2.40)^{*}\end{array}$ & $\begin{array}{l}-0.074 \\
(-3.62)\end{array}$ & $\begin{array}{l}-0.074 \\
(-3.61)\end{array}$ \\
\hline LEV & $\begin{array}{l}0.022 \\
(5.74)^{*}\end{array}$ & $\begin{array}{l}0.022 \\
(5.74)^{*}\end{array}$ & $\begin{array}{l}0.071 \\
(5.31)^{*}\end{array}$ & $\begin{array}{l}0.071 \\
(5.28)^{*}\end{array}$ \\
\hline LEVSQ & $\begin{array}{l}-0.031 \\
(-8.62)^{*}\end{array}$ & $\begin{array}{l}-0.031 \\
(-8.62)^{*}\end{array}$ & $\begin{array}{l}-0.127 \\
(-6.57)^{*}\end{array}$ & $\begin{array}{l}-0.127 \\
(-6.57)^{*}\end{array}$ \\
\hline SIZE & $\begin{array}{l}0.004 \\
(13.00)^{*}\end{array}$ & $\begin{array}{l}0.004 \\
(13.03)^{*}\end{array}$ & $\begin{array}{l}0.01 \\
(16.07)^{*}\end{array}$ & $\begin{array}{l}0.01 \\
(16.11)^{*}\end{array}$ \\
\hline HUMAN & $\begin{array}{l}0.027 \\
(3.52)^{*}\end{array}$ & $\begin{array}{l}0.027 \\
(3.52)^{*}\end{array}$ & $\begin{array}{l}0.055 \\
(2.99)^{*}\end{array}$ & $\begin{array}{l}0.055 \\
(2.98)^{*}\end{array}$ \\
\hline OPERATING & $\begin{array}{l}-0.012 \\
(-1.47)\end{array}$ & $\begin{array}{l}-0.012 \\
(-1.57)\end{array}$ & $\begin{array}{l}-0.006 \\
(-0.29)\end{array}$ & $\begin{array}{l}-0.006 \\
(-0.29)\end{array}$ \\
\hline HANOI & $\begin{array}{l}-0.005 \\
(-10.98)^{*}\end{array}$ & $\begin{array}{l}-0.005 \\
(-11.17)^{*}\end{array}$ & $\begin{array}{l}-0.015 \\
(-7.92)^{*}\end{array}$ & $\begin{array}{l}-0.015 \\
(-8.16)^{*}\end{array}$ \\
\hline HOCHIMINH & $\begin{array}{l}0.002 \\
(3.01)^{*}\end{array}$ & $\begin{array}{l}0.002 \\
(2.95)^{*}\end{array}$ & $\begin{array}{l}0.002 \\
(1.49)\end{array}$ & $\begin{array}{l}0.002 \\
(1.35)\end{array}$ \\
\hline INDUSTRIALPARK & $\begin{array}{l}0.002 \\
(0.71) \\
\end{array}$ & & $\begin{array}{l}0.012 \\
(1.23) \\
\end{array}$ & \\
\hline
\end{tabular}

Notes: t-statistics in the parentheses; * significant at $1 \%$ level.

\subsection{Discussion about the Findings}

Leverage and Squared Leverage term

The result shows that the coefficient of LEV is positive and significant. It is better to say that the impact of capital structure on 
firm performance is actually positive. Similarly, a higher level of debt is related to better firm performance. This finding is consistent with Jensen (1986), Berger and Bonaccora (2006), Salim and Yadav (2012). This finding is in contrast with Nguyen and Nguyen (2015) who revealed that firm performance is negatively associated with capital structure. The coefficient of LEVSQ is negative and also significant. An inverted U-shaped relationship might be appeared from the influence of the leverage on firm performance. This evidence is explained that in the real life, appearing of taxes, a company can acquire benefit the tax so called tax shield (Westerfield \& Jordan, 2011; Iavorskyi, 2013). In addition, the absence of bankruptcy cost, a firm with a higher level of debt in the capital structure is associated with a higher level of financial distress cost.

\section{Firm Size}

In respect to Firm Size, the coefficient is positive and significant. Showing that the firm size has positively significant relationship with the performance of the firm. It reveals that an increase in firm size will accelerate the performance of the firm. Besides the evidence, t-statistics is very high in consistent with a strong effect. It is correlated with the findings of Nguyen and Nguyen (2015) who conducting in 147 companies on Ho Chi Minh City Stock Exchange as well as the study of Emin (2016) who conducting in Turkey during 2006-2014. This finding is easy to explain in terms of micro-economy, a larger firm is often more efficient due to the economies of scale.

\section{Human Capital}

It is essential to understand human capital as a stock of technically qualified employees in employment, the level of education of the managers. In the construction industry, the finding is said that a firm with a higher level of human capital is positively associated with a higher level of performance which is in line with the findings of Gashi (2014) who indicated that human capital as assets does not follow the law of diminishing marginal utility. The evidence is also connected with the findings in the studies of Samagaio and Rodrigues (2016); Lehtimaki and Lehtimaki (2016); Ruíz et al. (2017); Khan and Quaddus (2017). Consequently, using optimal human resources, firms' performance can strongly increase.

\section{Operating Status, Region (Hanoi, Ho Chi Minh) and Industrial Park}

A dummy of operating of the firm. An insignificant negative effect of operating status on firm performance is found. In addition, it is evident to conclude that a firm locating in Hanoi's area may have a significant, negative impact on firm performance. A significant, positive relationship for a firm locating in the metropolitan of Ho Chi Minh and performance has been found. The results also indicate that firms locating in the region of Ho Chi Minh have a better performance than firms locating in the region of Hanoi. In fact, Ho Chi Minh is known as the better place to do business than Hanoi, especially for private companies like construction industry. Following is the business placement related to the performance, an insignificant positive effect of a firm locating in the industrial park on firm performance has been found. Similarly, the construction firm is not likely to situate in the industrial park. Table 2 presents that only 0.86 percent of construction firms (or 4186 companies) operating in the industrial park. As shown by Zheng et al. (2015), the proximity to the industrial park may reduce the costs of moving goods, ideas and people, however, this advantage of construction industry has not happened.

\section{Conclusion}

The study has estimated the impact of capital structure choice, human capital on firm performance in a developing country like Vietnam and using the dataset of 2016 Vietnamese Firm. Using a dataset of 48.673 observations and two accounting-based measures of firm performance; i.e. ROE and ROA. The empirical results present that a firm using more debt in capital structure can positively impact on firm performance but this effect is like an inverted U-shaped curve. Furthermore, a higher level of firm size as well as a higher level of human capital can increase the performance of the firm. The finding also indicated that a firm locating in the metropolitan of Ho Chi Minh had a significant positive impact on firm performance. In other words, a firm locating in the region of Hanoi may have significantly negative impact on firm performance. Finally, operating status and industrial park do not have any impact on the performance of the firm.

\section{References}

Adachi-Sato, M., \& Vithessonthi, C. (2019). Corporate debt maturity and future firm performance volatility. International Review of Economics \& Finance, 60, 216-237.

Berger, A., \& Bonaccora, E. (2006). Capital structure and firm performance: A new approach to testing agency theory and an application to the banking industry. Journal of Banking \& Finance, 30(4), 1065-1102.

Dollar, D. (2002). Reform, growth, and poverty in Vietnam. Policy, Research Working Paper. Washington DC: World Bank. Eesley, C.E., \& Roberts, E.B. (2012). Are you experienced or are you talented?: When does innate talent vs. experience explain 
entrepreneurial performance?. Strategic Entrepreneurship Journal, 6(3), 207-219.

Emin, A. (2016). Capital Structure and Firm Performance: An Application on Manufacturing Industry. Journal of Economics \& Administrative Sciences, 38(1), 15-30.

Gashi, P. (2014). Human capital and export decisions: The case of small and medium enterprises in Kosovo. Croatian Economic Survey, 16(2), 91-120.

Iavorskyi, M. (2013). The Impact of Capital Structure on Firm Performance: Evidence from Ukraine. Kyiv School of Economics, Ukraine.

Ibhagui, O.W., \& Olokoyo, F.O. (2018). Leverage and firm performance: New evidence on the role of firm size. The North America Journal of Economics and Finance, 45, 58-72.

Jensen, M. (1986). Agency cost of free cash flow, corporate finance, and takeovers: Corporate finance, and takeovers. American Economic Review, 76(2), 323-329.

Jensen, M.C., \& Meckling, W.H. (1976). Theory of the firm: Managerial behavior, agency costs and ownership structure. Journal of Financial Economics, 3(4), 305-360.

Khan, E.A., \& Quaddus, M. (2017). Dimensions of human capital and firm performance: Micro-firm context. IIMB Management Review, 30(3), 229-241.

Lehtimaki, J., \& Lehtimaki, J. (2016). The impact of knowledge capital on performance of firms: A case of firms in Finland. Eurasian Journal of Business and Economics, 9(18), 41-59.

McConnell, J.J., \& Servaes, H. (1995). Equity ownership and the two faces of debt. Journal of Financial Economics, 39(1), 131-157.

Modigliani, F., \& Miller, M., (1963). Corporate income taxes and the cost of capital: A correction. The American Economic Review, 53(3), 433-443.

Myers, S.C., \& Majluf, N.S. (1984). Corporate financing and investment decisions when firms have information that investors do not have. Journal of Financial Economics, 13(2), 187-221.

Nguyen, A.N., \& Nguyen, T. (2007). Foreign direct investment in Vietnam: An overview and analysis of the determinant of spatial distribution across provinces. Development and Policies Research Center, Working Paper, Hanoi.

Nguyen, T và Nguyen, H.C. (2015). Capital structure and firms' performance: Evidence from Vietnam's stock exchange. International Journal of Economics and Finance, 7(12), 1-10.

OECD (2002). Foreign direct investment for development: Maximum benefits and minimum costs. OECD Publications Service, Paris, France.

Ployhart, R. E. and Moliterno, T. P. (2011). Emergence of the Human Capital Resource: A Multilevel Model. The Academy of Management Review, 36(1), 127-150.

Ruíz, M. D. A., Gutiérrez, J. O., Martínez-Caro, E., \& Cegarra-Navarro, J. G. (2017). Linking an unlearning context with firm performance through human capital. European Research on Management and Business Economics, 23(1), 16-22.

Salim, M., \& Yadav, R. (2012). Capital structure and firm performance: Evidence from Malaysian listed companies. Procedia - Social and Behavioral Sciences, 65, 156-166.

Samagaio, A., \& Rodrigues, R. (2016). Human capital and performance in young audit firms. Journal of Business Research, 69(11), 5354-5359.

State Bank Vietnam (2012). Some solutions for the real estate market in Vietnam to develop sustainably under current conditions. Retrieved September 2, 2019, from https://www.sbv.gov.vn

Vătavu, S. (2015). The impact of capital structure on financial performance in Romania listed companies. Procedia Economics and Finance, 32, 1314-1322.

VCCI (2019). The summaries of Vietnam's FTA to July 2019. Retrieved September 2, 2019, from http://www.trungtamwto.vn/thong-ke/

Vietnamese National Productivity Institute (2018). Report of Productivity in Vietnam. Retrieved September 2, 2019, from http://vnpi.vn/bao-cao-nang-suat-viet-nam-2017.htm

Westerfield, R., Ross, S.A. \& Jordan, B.D. (2011). Corporate Finance Essentials. Global Edition. Mc Graw-Hill Irwin (1803).

Wignaraja, G. (2011). FDI, Size, and Innovation: Influences on Firm-Level Exports in East Asia. TMD Working Paper Series No.04. University of Oxford.

Wignaraja, G. (2008). FDI and Innovation as Drivers of Export Behavior: Firm- Level Evidence from East Asia. UNU-MERIT Working Paper Series 061. Asian Development Bank.

World Bank (2011). Vietnam Development Report 2012: Market Economy for a Middle Income Vietnam. Washington, D.C: World Bank.

Zheng, S., Wu, W., \& Kahn, M. (2015). The birth of edge cities in China: Measuring the effects in industrial parks policy. Journal of Urban Economics, 100(c), 80-103. 
(C) 2019 by the authors; licensee Growing Science, Canada. This is an open access article distributed under the terms and conditions of the Creative Commons Attribution (CC-BY) license (http://creativecommons.org/licenses/by/4.0/). 